\title{
The Impact of Gender and Body Mass Index on Lipid Profile of Diabetic Patients Treated in Royal Medical Services
}

\author{
Hussein H Dmour*, Eman F Khreisat and Shereen Abdullah Hasan \\ Jordan Royal Medical Services, Jordan
}

Received: 非: December 26, 2018; Published: 非: January 09, 2019

*Corresponding author: Hussein H Dmour, Jordan Royal Medical Services, Jordan

\begin{abstract}
Introduction: Diabetes mellitus is prevalent all over the world and it is expected to have more than 300 million patients by 2030. Diabetes is affected by various factors such as stress, obesity and others.

Objectives: The main objective of this study is to investigate the impact of gender and body mass index on lipid profile of diabetic patients treated in the outpatient clinics at King Hussein Medical Center, Royal Medical Services, Jordan.

Methodology: This is a retrospective study and files of patients were reviewed if they were appropriated for this study in terms of the data content compatibility. It should be clearly apparent in files that such important data indicating gender, age, body mass index and lipid profile for each patient exist. A total of 62 files of diabetic patients were selected. A working excel sheet will was created and prepared for data collection. After the entry of all data had been completed, data were analyzed statistically using SPSS version 21.
\end{abstract}

Results: The mean age of study participants was $57 \pm 12$ years. As shown by body mass index $\left(31.5 \pm 21 \mathrm{~kg} / \mathrm{m}^{2}\right)$, study participants were obese. Lipid profile was abnormal. Body mass index had impacts on lipid profile of diabetic patients, while gender had no impacts on lipid profile of diabetic patients. Correlation was positively and significantly between age and low-density lipoprotein, and between cholesterol and each of triglyceride, high density lipoprotein, and low-density lipoprotein.

Conclusion: The present study showed that obesity as represented by high body mass index has impacts on lipid profile of diabetic patients. On the other hand, gender had no impact on lipid profile of the same patients. Pearson correlation was positively and significantly between cholesterol and triglycerides, high density lipoprotein, and low-density lipoprotein which showed the effect of insulin insufficiency.

Keywords: Diabetes; Gender; Body Mass Index; Lipid Profile

\section{Introduction}

Diabetes is a systematic disease and its impacts various organs and systems in the body among which is the cardiovascular system. Diabetes is a real risk for cardiovascular diseases and significantly associated with increasing rates of mortality and morbidity among diabetics [1] (Omotoye and Fadupin). Diabetes mellitus is considered as a chronic disease that needs continuous medical care and special attention to cope with possible occurrence of its complications [2]. Dyslipidemia is one of risk factors that are associated with cardiovascular diseases [3]. Dyslipidemia is more likely to be encountered in patients with diabetes mellitus because insulin related problems such as deficiency and resistance have effects on lipid metabolism [4]. Dyslipidemia among diabetics has the following pattern: Increased levels of triglycerides, low levels of high-density lipoprotein and increased levels of lowdensity lipoproteins. Diabetic dyslipidemia is associated with heart diseases and it is expected that abnormal levels of serum lipids to contribute in the occurrence of coronary artery disease [1]. The rates of obesity have increased overtime, particularly in developed countries and this was observed to go side by side with increased diabetic prevalence [5]. From epidemiologic point of view, obese individuals (body mass index $>35$ ) have larger probabilities compared with non-obese persons to develop diabetes mellitus [6]. However, body mass index is considered as an important predictor of cardiovascular disease and diabetes mellitus [7]. The definition of obesity depends on the level of Body Mass Index (BMI) $>30 \mathrm{~kg} /$ $\mathrm{m}^{2}[8]$. 


\section{Study Objectives}

The main objective of this study is to investigate the impact of gender and body mass index on lipid profile of diabetic patients treated in the outpatient clinics at King Hussein Medical Center, Royal Medical Services, Jordan.

\section{Methods and patients}

Study design: A retrospective study was conducted.

Study sample: A total of 62 diabetic profiles were included in this study for analysis.

Study procedure: After the study had been approved by Institutional Review Board (IRB) of Royal Medical Services, Jordan, the research team started reviewing patient files. Files were valid if medical information of interest were completely involved such as gender, diabetic status, body mass index, and lipid profile. Data were collected from files and entered excel sheet to keep raw data. Following the data collection, data were analyzed using SPSS version 21. Various statistical analyses were performed. Descriptive analysis was firstly applied to describe data which were presented as frequency and percentages for categorized variables such as gender. Other non-categorized variables were presented as means and standard deviations. T test was carried out to investigate the relationships between body mass index and lipid profile variables including cholesterol, triglycerides, high density lipoproteins, and low-density lipoproteins. The relationships between gender and lipid profile variables were carried out using One Way Anova. The correlation between study variables was conducted using Pearson correlation. The significance was considered at $\alpha \leq 0.05$.

\section{Results}

As shown in Table 1, the general characteristics of study participants showed that the mean age was $57 \pm 12$ years. A total of $33(53.2 \%)$ of participants were males. The mean of BMI was $31.5 \pm 21 \mathrm{~kg} / \mathrm{m} 2$, the mean of glucose was $239 \pm 85 \mathrm{mg} / \mathrm{dl}$, the cholesterol mean was $218 \pm 52 \mathrm{mg} / \mathrm{dl}$, the mean level of triglyceride was $247 \pm 172 \mathrm{mg} / \mathrm{dl}$, the mean level of HDL was $46 \pm 13 \mathrm{mg} / \mathrm{dl}$, and the mean level of LDL was $118 \pm 41 \mathrm{mg} / \mathrm{dl}$.

Table 3: The relationship between gender and lipid profile (One Way Anova).

\begin{tabular}{|c|c|c|c|c|c|c|}
\hline \multicolumn{2}{|c|}{ Variables } & \multirow{2}{*}{\begin{tabular}{c|} 
Sum of Squares \\
29.723
\end{tabular}} & \multirow[t]{2}{*}{ df } & \multirow{2}{*}{$\begin{array}{l}\text { Mean Square } \\
29.723 \\
\end{array}$} & \multirow{2}{*}{$\begin{array}{c}\mathbf{F} \\
0.011\end{array}$} & \multirow{2}{*}{$\begin{array}{c}\text { P value } \\
0.917\end{array}$} \\
\hline Cholesterol & Between Groups & & & & & \\
\hline & Within Groups & 162203.051 & 60 & 2703.384 & & \\
\hline & Total & 162232.774 & 61 & & & \\
\hline \multirow[t]{3}{*}{$\mathrm{TG}$} & Between Groups & 25236.465 & 1 & 25236.465 & 0.847 & 0.361 \\
\hline & Within Groups & 1787863.277 & 60 & 29797.721 & & \\
\hline & Total & 1813099.742 & 61 & & & \\
\hline \multirow[t]{3}{*}{ HDL } & Between Groups & 303.209 & 1 & 303.209 & 1.814 & 0.184 \\
\hline & Within Groups & 8861.201 & 53 & 167.192 & & \\
\hline & Total & 9164.410 & 54 & & & \\
\hline \multirow[t]{3}{*}{ LDL } & Between Groups & 41.978 & 1 & 41.978 & 0.024 & 0.877 \\
\hline & Within Groups & 88781.570 & 51 & 1740.815 & & \\
\hline & Total & 88823.547 & 52 & & & \\
\hline
\end{tabular}

Table 1: General characteristics of participants.

\begin{tabular}{|c|c|}
\hline Variable & Description \\
\hline Age $(\mathrm{M} \pm \mathrm{SD}$ ) years & $57 \pm 12$ \\
\hline $\begin{array}{c}\text { Gender }(\mathrm{N}, \%): \\
\text { a) Males } \\
\text { b) Females }\end{array}$ & $33(53.2 \%)$ \\
\hline BMI $(\mathrm{M} \pm \mathrm{SD}) \mathrm{kg} / \mathrm{m}^{2}$ & $29(46.8 \%)$ \\
\hline Glucose $(\mathrm{M} \pm \mathrm{SD}) \mathrm{mg} / \mathrm{dl}$ & $31.5 \pm 21$ \\
\hline Cholesterol $(\mathrm{M} \pm \mathrm{SD}) \mathrm{mg} / \mathrm{dl}$ & $239 \pm 85$ \\
\hline Triglyceride $(\mathrm{M} \pm \mathrm{SD}) \mathrm{mg} / \mathrm{dl}$ & $218 \pm 52$ \\
\hline HDL $(\mathrm{M} \pm \mathrm{SD}) \mathrm{mg} / \mathrm{dl} \mathrm{mg} / \mathrm{dl}$ & $247 \pm 172$ \\
\hline LDL $(\mathrm{M} \pm \mathrm{SD}) \mathrm{mg} / \mathrm{dl} \mathrm{mg} / \mathrm{dl}$ & $46 \pm 13$ \\
\hline
\end{tabular}

The Relationship between BMI and Lipid Profile: We investigated the relationship between BMI and lipid profile variables using $\mathrm{T}$ test. The results showed that there were significant relationships between BMI and Cholesterol $(\mathrm{p}<0.001)$, BMI and triglycerides $(\mathrm{p}<0.001)$, BMI and HDL $(\mathrm{p}<0.001)$, BMI and LDL ( $\mathrm{p}<0.001)$ (Table 2).

Table 2: The relationship between BMI and lipid profile.

\begin{tabular}{|c|c|c|}
\hline Variables & M \pm SD & P value \\
\hline BMI & $31 \pm 21$ & $<0.001$ \\
Cholesterol & $218 \pm 52$ & $<0.001$ \\
\hline BMI & $31 \pm 21$ & $<0.001$ \\
TG & $247 \pm 172$ & \\
\hline BMI & $31 \pm 21$ & $<0.001$ \\
\hline HDL & $46 \pm 13$ & \\
\hline BMI & $31 \pm 21$ & $118 \pm 41$ \\
\hline LDL &
\end{tabular}

The Relationship between Gender and Lipid Profile: To investigate the impact of gender on lipid profile variable, One Way Anova test was used. The results as shown in Table 3 did not reveal any significant impact of gender on any of lipid profile variables $(\mathrm{p}>0.05)$. 
Correlation between Study Variables: We investigated the possible correlations in study variables using Pearson correlation. We found positive and significant correlation between age and LDL $(r=0.276, p=0.045)$, cholesterol and triglycerides $(r=0.487$, $\mathrm{p}<0.001)$, cholesterol and HDL $(\mathrm{r}=0.283, \mathrm{p}=0.036)$, and cholesterol and LDL ( $\mathrm{r}=0.626, \mathrm{p}<0.001)$ (Table 4).

Table 4: Correlation between study variables.

\begin{tabular}{|c|c|c|}
\hline Variables & Correlation & P value \\
\hline $\begin{array}{c}\text { Age } \\
\text { LDL }\end{array}$ & 0.276 & 0.045 \\
\hline $\begin{array}{c}\text { Cholesterol } \\
\text { Triglyceride }\end{array}$ & 0.487 & $<0.001$ \\
\hline $\begin{array}{c}\text { Cholesterol } \\
\text { HDL }\end{array}$ & 0.283 & 0.036 \\
\hline $\begin{array}{c}\text { Cholesterol } \\
\text { LDL }\end{array}$ & 0.626 & $<0.001$ \\
\hline
\end{tabular}

\section{Discussion}

The present study was conducted to investigate the impacts of gender and body mass index on lipid profile of diabetic patients. The results of the present study showed that the mean level of glucose was $239 \pm 85 \mathrm{mg} / \mathrm{dl}$. The purpose of various diabetic treatments is to keep glucose level $\leq 130 \mathrm{mg} / \mathrm{dl}[9,10]$. The mean level of body mass index was $31.5 \pm 21$ which implies that the participants were obese, and this finding agrees with other reported studies in literature in which the obesity was considered if the level of Body Mass Index (BMI) is more than $30 \mathrm{~kg} / \mathrm{m} 2$ [8]. Other studies have confirmed that obesity and body mass index are risk factors for developing diabetes and cardiovascular diseases [6,7]. All values of lipid profile were abnormal although patients received lipid lowering agents such as atorvastatin. We examined the impact of body mass index on profile lipids of diabetic patients using T test. The results pointed to significant relationships between BMI and all lipid profile parameters ( $\mathrm{p}<0.001$ for all). These findings are not surprising because dyslipidemia is more likely to occur in patients with diabetes mellitus due to insulin related problems such as deficiency and resistance that have effects on lipid metabolism [4]. The values of lipid parameters in our study are in consistent with other studies in which dyslipidemia among diabetics is associated with increased levels of triglycerides, low levels of high-density lipoprotein and increased levels of low-density lipoproteins [1,4]. The impact of gender on lipid profile of diabetic patients was examined using One Way Anova test. There was no significant relationship between gender and lipid profile parameters ( $p>0.05$, for all parameters). Our findings do not agree with other studies that reported diabetic women had higher risk factors for developing cardiovascular disease compared with their men counterparts $[11,12]$. We conducted Pearson correlation between study variables. The results showed that there was a positively significant correlation between age and low-density lipoprotein $(r=0.276, p=0.045)$. This finding may be explained by decreased physical activity as age increased. This is in line with other studies such as the study of Joshi et al. Cholesterol was also positively and significantly correlated with triglycerides, high density lipoprotein and low-density lipoprotein. This implies that the lipid metabolism is under control of insulin deficiency or resistance as mentioned previously [4].

\section{Conclusion}

The present study showed that obesity as represented by high body mass index has impacts on lipid profile of diabetic patients. On the other hand, gender had no impact on lipid profile of the same patients. Pearson correlation was positively and significantly between age and low-density lipoprotein and between cholesterol and triglycerides, high density lipoprotein and low-density lipoprotein which showed the effect of insulin insufficiency.

\section{References}

1. JA Kayode, AO Sola, AS Matthew, BO Adesola, I Ademola, et al. (2010) Lipid profile of type 2 diabetic patients at a rural tertiary hospital in Nigeria. J of Diabetes \& Endocrinology 1(4): 46-51.

2. Silva J, Souza E, Echazú Böschemeier AG, Costa C, Bezerra HS, et al. (2018) Diagnosis of diabetes mellitus and living with a chronic condition: participatory study. BMC public health 18(1): 699.

3. Elnaz ZE, Ramjan S, Shobha Rani RH, Chandrakant BP, Sunitha S (2018) Assessment of risk factors for the cardiovascular diseases in people visiting a tertiary care hospital for routine medical check-up. J of Cardiovascular Disease Res 9(1): 32-35.

4. Vergès B (2015) Pathophysiology of diabetic dyslipidaemia: where are we? Diabetologia. 58(5): 886-899.

5. Riaz S, Alam SS, Raza M, Hasnain S, Akhtar MW (2009) Obesity as risk factor and study of obesity related proteins in diabetes mellitus. Afr J Biotechnol 8(5): 737-744.

6. Han SJ, Boyko EJ (2018) The Evidence for an obesity paradox in type 2 diabetes mellitus. Diabetes Metab J 42(3): 179-187.

7. Tran N, Blizzard CL, Luong KN, Truong N, Tran BQ Otahal P, et al. (2018) The importance of waist circumference and body mass index in crosssectional relationships with risk of cardiovascular disease in Vietnam. PloS one 13(5): e0198202.

8. Nuttall FQ (2015) Body Mass Index: Obesity, bmi, and health: a critical review. Nutr Today 50(3): 117-128.

9. Algenstaedt, P, Stumpenhagen A, Westendorf J (2018) The Effect of morinda citrifolia 1 fruit juice on the blood sugar level and other serum parameters in patients with diabetes type 2. eCAM pp 10.

10. Chaudhury A, Duvoor C, Reddy Dendi VS, Shashank Kraleti, Aditya Chada, et al. (2017) Clinical review of antidiabetic drugs: Implications for type 2 diabetes mellitus management Frontiers in Endocrinology 8: 6.

11. Rachel H, Federica B, Mark W (2006) Excess risk of fatal coronary heart disease associated with diabetes in men and women: meta-analysis of 37 prospective cohort studies. BMJ 332: 73.

12. Walden CE, Knopp RH, Wahl PW (1984) Sex differences in the effect of diabetes mellitus on lipoprotein triglyceride and cholesterol concentrations. N Engl J Med 311(15): 953-959.

13. Funmilayo EO, Grace Tanimoowo F (2016) Effect of body mass index on lipid profile of type 2 diabetic patients at an urban tertiary hospital in nigeria. IOSR J of Den \& Med Sci 15(9): 65-70.

14. Raj J, Keshab B, Koushik KK, Sanjit P, Sandeep (2014) Correlation of type 2 diabetes mellitus and dyslipidemia among nepalese. Asian J of Pharmaceutical \& Clin Res 7(5): 295-299. 
ISSN: 2574-1241

DOI: 10.26717/BJSTR.2019.13.002335

Hussein H Dmour. Biomed J Sci \& Tech Res

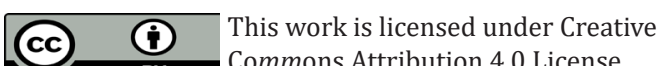

Submission Link: https://biomedres.us/submit-manuscript.php

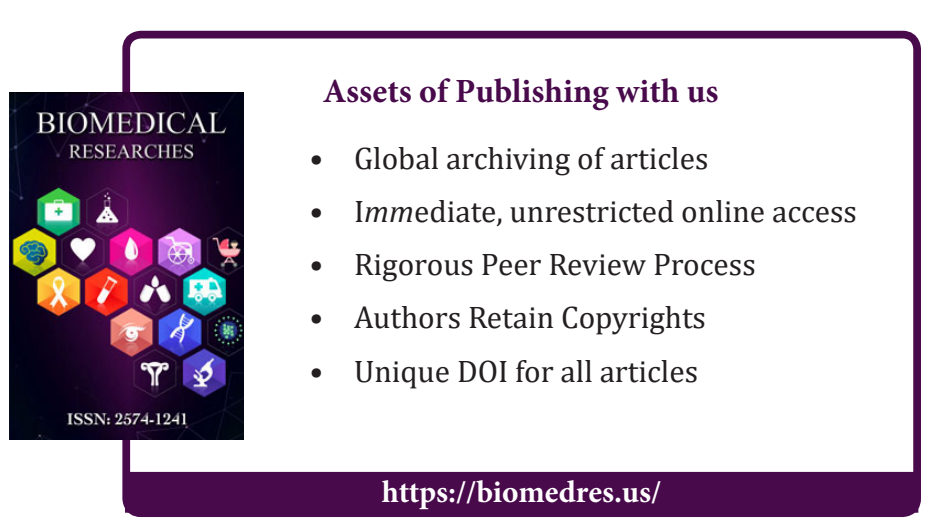

